\title{
Tribulus Terrestris for Female Sexual Dysfunction: A Systematic Review
}

\section{Tribulus terrestris para disfunção sexual feminina: Uma Revisão Sistemática}

\author{
Ana Luiza Cabrera Martimbianco ${ }^{10}$ Rafael Leite Pacheco ${ }^{10}$ Fábia Lima Vilarino ${ }^{10}$ \\ Carolina de Oliveira Cruz Latorraca ${ }^{1}$ () Maria Regina Torloni ${ }^{20}$ Rachel Riera $2,3(0)$
}

${ }^{1}$ Department of Medicine, Centro Universitário São Camilo, São

Address for correspondence Rafael Leite Pacheco, MD, Msc, Centro Camilo, SP, Brazil

Universitário São Camilo, São Camilo, SP, Brazil

2 Discipline of Evidence-Based Health, Universidade Federal de São (e-mail: rleitepacheco@hotmail.com).

Paulo, São Paulo, SP, Brazil

${ }^{3}$ Centre of Health Technology Assessment, Hospital Sirio-Libanês,

São Paulo, SP, Brazil

Rev Bras Ginecol Obstet 2020;42(7):427-435.

\section{Abstract}

\section{Keywords}

- tribulus

- sexual dysfunction

- review

- evidence-based medicine
Objective We performed a systematic review to assess the effectiveness and safety of Tribulus terrestris to treat female sexual dysfunction (FSD).

Data sources We performed unrestricted electronic searches in the MEDLINE, CENTRAL, EMBASE, LILACS, CINAHL, PsycINFO, WHO-ICTR, Clinicaltrials.gov and OpenGrey databases. Selection of studies We included any randomized controlled trials (RCTs) that compared $T$. terrestris versus inactive/active interventions. After the selection process, conducted by two reviewers, 5 RCTs ( $n=279$ participants) were included.

Data collection Data extraction was performed by two reviewers with a preestablished data collection formulary.

Data synthesis Due to lack of data and clinical heterogeneity, we could not perform meta-analyses. The risk of bias was assessed by the Cochrane Risk of Bias (RoB) tool, and the certainty of evidence was assessed with Grading of Recommendations, Assessment, Development and Evaluations (GRADE).

Results After 1 to 3 months of treatment, premenopausal and postmenopausal women randomized to $T$. terrestris had a significant increase in sexual function scores. Three months of treatment with $T$. terrestris showed a significant increase in the serum testosterone levels of premenopausal women. There was no report of serious adverse events, and none of the studies assessed health-related quality of life. The certainty of the evidence was very low, which means that we have very little confidence in the effect estimates, and future studies are likely to change these estimates.

Conclusion More RCTs are needed to support or refute the use of $T$. terrestris. The decision to use this intervention should be shared with the patients, and the uncertainties around its effects should be discussed in the clinical decision-making process.

Number of Protocol registration in PROSPERO database: CRD42019121130 received

September 24, 2019

accepted

March 16, 2020
DOI https://doi.org/

10.1055/s-0040-1712123. ISSN 0100-7203.
Copyright $\odot 2020$ by Thieme Revinter

Publicações Ltda, Rio de Janeiro, Brazil
License terms

(c) (9) 


\begin{abstract}
Resumo
Palavras-chave

- tribulus

- disfunção sexual

- revisão

- medicina baseada em evidências

Objetivo Nós realizamos uma revisão sistemática para avaliar a efetividade e a segurança do Tribulus terrestris no tratamento da disfunção sexual feminina (DSF). Fontes de dados Nós realizados uma busca eletrônica irrestrita nas seguintes bases de dados: MEDLINE, CENTRAL, EMBASE, LILACS, CINAHL, PsycINFO, WHO-ICTR, Clinicaltrials.gov, e OpenGrey.

Seleção dos estudos Nós incluímos todos os ensaios clínico randomizados (ECR) que comparou $T$. terrestris com controles ativos/inativos. Após o processo de seleção, conduzido por 2 revisores, 5 ECRs ( $n=279$ participantes) foram incluídos.

Extração de dados O processo de extração de dados foi realizado por dois revisores, utilizando-se um formulário de extração de dados pré-estabelecido.

Síntese de dados Devido à falta de dados disponíveis e à heterogeneidade clínica entre os estudos incluídos, nós não realizamos meta-análises. O risco de viés foi avaliado pela tabela de risco de viés da Cochrane e, a certeza do corpo da evidência foi avaliada pelo Grading of Recommendations, Assessment, Development and Evaluations (GRADE).

Resultados Após 1 a três 3 meses de tratamento, mulheres na pré e pós-menopausa randomizadas ao $T$. terrestris tiveram um aumento significante nos escores de função sexual. O grupo com 3 meses de tratamento com $T$. terrestris exibiu um aumento significante dos níveis séricos de testosterona em mulheres pré-menopausa. Não houve relato de eventos adversos graves, e nenhum estudo avaliou qualidade de vida das participantes. A certeza da evidência foi considerada muito baixa, o que significa que existe pouca certeza na estimativa dos efeitos e que é provável que futuros estudos mudem estas estimativas.

Conclusão Mais ECRs são importantes para apoiar ou refutar o uso do T. terrestris. A decisão de usar essa intervenção deve ser compartilhada com pacientes, e as incertezas sobre seus efeitos devem ser discutidas durante o processo de decisão clínica.
\end{abstract}

\section{Introduction}

Female sexual dysfunction (FSD) is a common condition associated with physical, psychological, and sociocultural factors. ${ }^{1-3}$ The International Society for the Study of Women's Sexual Health (ISSWSH) classifies FSD in four categories: hypoactive sexual desire disorder (HSDD), sexual arousal disorders (genital and cognitive), orgasmic disorders, and sexual pain disorders. ${ }^{4}$ In a large epidemiological study conducted over 10 years ago, $12 \%$ of 31,581 American women reported a distressing sexual problem, and the percentages were higher among older (45-64 years) participants. ${ }^{5}$ Up to 30 to $50 \%$ of women will have FSD during their lifetime, and this rate is probably underestimated due to the social aspects associated with this condition. ${ }^{3,4}$ An estimated $20 \%$ of women in all age groups have orgasmic disorders, and 10 to $16 \%$ have HSDD, while up to $15 \%$ of premenopausal and $30 \%$ of postmenopausal women have arousal difficulties. $2,4,6,7$

Standard care for FDS usually involves a multidisciplinary approach, including hormonal therapy, psychotherapy and pharmacological therapy, to address all components of the disorder. ${ }^{3}$ Medicinal plants have been increasingly used by women with FDS, often without a medical prescription. ${ }^{2}$

Tribulus terrestris L. (Zygophyllaceae) is a creeping herb, originally from India, which is used as a natural sexual stimulant. Tribulus extracts contain protodioscin, a steroidal saponin that can influence hormonal activity and affect the production of endogenous androgen by increasing the release of luteinizing hormone. ${ }^{2,8,9}$ However, the effects of this intervention have not been established. Therefore, the objective of this systematic review was to evaluate the effectiveness and safety of $T$. terrestris for the treatment of FDS (-Table 1).

\section{Methods}

\section{Study Design}

We registered the protocol of the present study with the International Prospective Register of Systematic Reviews (PROSPERO) (CRD42019121130). The current systematic review of the literature followed the methodological recommendations of the Cochrane Handbook for Systematic Reviews of Interventions ${ }^{15}$ and the reporting recommendations of the Preferred Reporting Items for Systematic Reviews and Meta-Analyses (PRISMA) statement. ${ }^{16}$

\section{Inclusion Criteria}

Types of Studies

We included only randomized clinical trials (RCTs). 
Table 1 Main characteristics of the included studies

\begin{tabular}{|c|c|c|c|c|c|}
\hline Study (year) & Participants & $\begin{array}{l}\text { Interventions and com- } \\
\text { parators }\end{array}$ & Outcomes & Follow-up & Funding \\
\hline $\begin{array}{l}\text { Vale et al } \\
(2018)^{10}\end{array}$ & $\begin{array}{l}\mathrm{N}=40 \\
\text { premenopausal } \\
\text { women with HSDD } \\
\text { Age } 18 \text { to } 44 \text { years }\end{array}$ & $\begin{array}{l}\mathrm{G} 1: \text { T. terrestris }(N=20)^{*} \\
250 \text { mg orally } 3 \text { times/day, } \\
120 \text { days } \\
\text { G2: Placebo }(N=20)^{*}\end{array}$ & $\begin{array}{l}\text { Sexual Function } \\
\text { (FSFI and SQ-F) } \\
\text { Serum testosterone } \\
\text { level }\end{array}$ & $\begin{array}{l}\text { Immediately } \\
\text { after treatment } \\
\text { (4 months) }\end{array}$ & No financial support \\
\hline $\begin{array}{l}\text { Souza et al } \\
(2016)^{11}\end{array}$ & $\begin{array}{l}\mathrm{N}=46 \\
\text { postmenopausal } \\
\text { women with HSDD } \\
\text { Age } 43 \text { to } 65 \text { years }\end{array}$ & $\begin{array}{l}\mathrm{G} 1: \text { T. terrestris }(N=20)^{*} \\
250 \text { mg orally } 3 \text { times/day, } \\
120 \text { days } \\
\text { G2: Placebo }(N=16)^{*}\end{array}$ & $\begin{array}{l}\text { Sexual Function } \\
\text { (FSFI) } \\
\text { Serum testosterone } \\
\text { level }\end{array}$ & $\begin{array}{l}\text { Immediately } \\
\text { after treatment } \\
\text { (4 months) }\end{array}$ & $\begin{array}{l}\text { A pharmacy provided } \\
\text { T. terrestris used in the } \\
\text { study }\end{array}$ \\
\hline $\begin{array}{l}\text { Postigo et al } \\
(2016)^{12}\end{array}$ & $\begin{array}{l}\mathrm{N}=60 \\
\text { postmenopausal } \\
\text { women with HSDD } \\
\text { Age: } \\
\text { G1 } 54 \pm 5.1 \text { years } \\
\text { G2 } 56 \pm 5.8 \text { years }\end{array}$ & $\begin{array}{l}\text { G1: } T \text {. terrestris }(N=30)^{*} \\
250 \text { mg orally } 3 \text { times/day, } \\
90 \text { days } \\
\text { G2: Placebo }(N=30)^{*}\end{array}$ & $\begin{array}{l}\text { Sexual Function } \\
(\mathrm{SQ}-\mathrm{F})\end{array}$ & $\begin{array}{l}\text { Immediately } \\
\text { after treatment } \\
\text { (3 months) }\end{array}$ & $\begin{array}{l}\text { The study received } \\
\text { funding from a } \\
\text { governmental fund and } \\
\text { the main investigator } \\
\text { had a research } \\
\text { fellowship. }\end{array}$ \\
\hline $\begin{array}{l}\text { Guazzelli et al } \\
(2014)^{13}\end{array}$ & $\begin{array}{l}\mathrm{N}=66 \\
\text { postmenopausal } \\
\text { women with HSDD } \\
\text { Age } \\
\text { G1 } 56 \pm 5.8 \text { years } \\
\text { G2 } 53 \pm 3.9 \text { years } \\
\text { G3 } 54 \pm 5.1 \text { years }\end{array}$ & $\begin{array}{l}\text { G1: } T \text {. terrestris }(N=22)^{*} \\
250 \text { mg orally } 3 \text { times/day, } \\
90 \text { days } \\
\text { G2: Tibolone }(N=24)^{*} \\
1.25 \text { mg/oral } \\
\text { administration/day, } \\
90 \text { days } \\
\text { G3: Placebo }(N=20)\end{array}$ & $\begin{array}{l}\text { Sexual Function } \\
(\mathrm{SQ}-\mathrm{F})\end{array}$ & $\begin{array}{l}\text { Immediately } \\
\text { after treatment } \\
\text { (3 months) }\end{array}$ & $\begin{array}{l}\text { The study received } \\
\text { funding from a } \\
\text { governmental fund }\end{array}$ \\
\hline $\begin{array}{l}\text { Akhtari et al } \\
(2014)^{14}\end{array}$ & $\begin{array}{l}\mathrm{N}=67 \\
\text { premenopausal } \\
\text { women with HSDD } \\
\text { Age } \\
\text { G1 } 36 \pm 6.2 \text { years } \\
\text { G2 } 36.1 \pm 5.8 \text { years }\end{array}$ & $\begin{array}{l}\text { G1: } T \text {. terrestris }(N=30)^{*} \\
7.5 \mathrm{ml} \text { syrup, } 2 \text { times / day, } \\
30 \mathrm{days} \\
(3.5 \mathrm{~g} \text { of ethanolic extract } \\
\text { per } 5 \mathrm{ml} \text { of syrup) } \\
\text { G2: Placebo }(N=30)^{*}\end{array}$ & $\begin{array}{l}\text { Sexual Function } \\
\text { (FSFI)/p>Adverse } \\
\text { events }\end{array}$ & $\begin{array}{l}\text { Immediately } \\
\text { after treatment } \\
\text { (1 month) }\end{array}$ & $\begin{array}{l}\text { The study was } \\
\text { supported by Tehran } \\
\text { University of Medical } \\
\text { Sciences; it is not clear } \\
\text { if this was } \\
\text { financial support }\end{array}$ \\
\hline
\end{tabular}

Abbreviations: FSFI, Female Sexual Function Index; g, grams; HSDD, hypoactive sexual desire disorder; mg: milligrams; ml, milliliters; N, number of participants; SQ-F, Sexual Quotient Female Questionnaire; T. terrestris, Tribulus terrestris.

*Number of patients included in the analysis.

\section{Types of Participants}

We included trials that recruited women (aged 16 or over) with a clinical diagnosis of any type of female sexual dysfunction.

\section{Types of Interventions}

All RCTs that tested $T$. terrestris in any dose, regimen, route of delivery, and for any duration, were eligible for inclusion in the review. The studies had to compare this intervention versus placebo, no intervention, or any active treatment. Trials that administered $T$. terrestris combined with another intervention were eligible if the effects of $T$. terrestris could be isolated.

\section{Outcomes}

Primary Outcomes:

a) Sexual function assessed by validated tools, such as the Female Sexual Function Index (FSFI) ${ }^{17}$ and Sexual Quotient Female Version (SQ-F). ${ }^{18}$

b) Health-related quality of life assessed by any general or specific validated tool.

c) Serious adverse events defined as the proportion of patients who had at least one life-threating adverse event that resulted in hospitalization, disability or incapacity. Secondary outcomes:

d) Serum testosterone levels measured by any laboratory exam. e) Minor adverse events defined as the proportion of participants presenting at least one minor adverse event.

We considered all time-points reported in the RCTs. We intended to pool (in metanalyses) only similar time points: short term (up to 3 months), middle term (between 3 and 6 months) and long term (more than 6 months).

\section{Search for Studies}

We created a broad and sensitive search strategy, without language, date, or publication status restrictions, to identify all potentially relevant studies.

\section{Electronic Search}

We ran the search in the following electronic databases to identify studies published from inception to February 11, 2019: MEDLINE (via Pubmed), Cochrane Central Register of Controlled Trials - CENTRAL (via Wiley), EMBASE (via Elsevier), Literatura Latino Americana em Ciências da Saúde e do Caribe - LILACS (via Biblioteca Virtual em Saúde [BVS]), Cumulative Index to Nursing and Allied Health Literature - CINAHL (EBSCO host), and PsycINFO (via American Psychological Association). See complete search strategies and all terms used in the searches in -Supplementary Table S1. 


\section{Search for Ongoing Studies}

We searched for ongoing studies in the World Health Organization (WHO) International Clinical Trials Registry Platform (apps.who.int/trialsearch) and in ClinicalTrials.gov (www.clinicaltrials.gov).

Hand Search and Search for Unpublished Studies We searched for unpublished studies in Open Gray (http:// www.opengrey.eu/). We contacted experts in the field to inquire about any additional ongoing or unpublished studies. We also screened the reference lists of all included studies to identify additional potentially relevant trials.

\section{Process of Study Selection}

We used the Rayyan software ${ }^{19}$ in the two phases of the study selection process. In the first phase, two authors (RLP and COCL) independently screened the titles and abstracts of all records retrieved through the search strategy. In the second phase, the same two authors independently read the full texts of the records coded as 'potentially relevant' and included those that fulfilled the aforementioned selection criteria. We created a table with reasons for exclusion of the studies in this phase of the selection process. When needed, a third review author (RR) solved disagreements.

\section{Data Extraction}

We used a data extraction form especially created for this review to collect relevant information from each included trial. Two independent review authors (RLP and ALCM) extracted data; a third author (RR) solved any disagreements.

\section{Assessment of the Risk of Bias}

We used the Cochrane risk of bias tool to assess the methodological quality of the included trials. This tool assesses seven domains of each RCT: random sequence generation, allocation concealment, blinding of participants and personnel, blinding of outcome assessors, incomplete outcome data, selective reporting of outcomes, and other potential sources of bias. ${ }^{15}$ Two authors (RLP and DVP) performed these assessments independently; a third author (RR) solved disagreements.

\section{Heterogeneity Between Included Studies}

We planned to assess the heterogeneity of the intervention effects by visual inspection of the forest plots. We planned to use the chi-squared test $(p>0.1)$ as indicative of statistical heterogeneity (inconsistency), and the I-squared test to measure the extent of heterogeneity $\left(\mathrm{I}^{2}>50\right.$ being indicative of significant heterogeneity). ${ }^{15}$ We also planned to examine the reasons for heterogeneity by conducting additional analyses. This was not possible due to lack of data.

\section{Measures of Treatment Effect and Analysis}

For dichotomous outcomes, we report results using risk ratios (RRs); for continuous outcomes, we used mean differences (MDs). We calculated the 95\% confidence intervals (CI) for all reported outcomes. Where possible (availability and homogeneity of data), we planned to pool treatment effects of individual trials into metanalyses using a random effects model and the Review Manager 5.3 software (The Nordic Cochrane Centre/The Cochrane Collaboration, Copenhagen, Denmark). ${ }^{20}$ This was not possible.

\section{Subgroup and Sensitivity Analyses}

We planned to perform subgroup analyses for all primary outcomes comparing pre and postmenopausal women. We also planned to perform two sensitivity analyses for all primary outcomes: random-effects versus fixed-effect metanalyses, and trials with low versus high or unclear risk of selection, detection, performance, and attrition bias. However, due to lack of data, we could not perform these analyses.

\section{Publication Bias Assessment}

We planned to investigate publication bias using funnel plots in metanalyses with more than 10 studies. This was not possible due to lack of data.

\section{Assessing the Certainty of the Evidence}

We used the Grading of Recommendations, Assessment, Development and Evaluations (GRADE) approach ${ }^{21}$ to evaluate the certainty of the body of evidence for the comparison between $T$. terrestris versus placebo for the primary outcomes. We assessed the certainty of the evidence in all five GRADE domains (risk of bias, inconsistency, imprecision, indirectness, and publication bias). We report reasons to downgrade or upgrade the evidence. We present a summary of findings table using the software GRADEpro GDT (McMaster University, Hamilton, ON, Canada). ${ }^{22}$

\section{Results}

\section{Search Results}

The search strategy retrieved 1,258 references. After the exclusion of 16 duplicates, we screened 1,242 unique references, excluded 1,236, and selected 6 for full text reading. One was an ongoing trial (IRCT2016121131340N1) that may contribute data in future updates of this review (-Supplementary Table S2). Thus, 5 RCTs were included in the review (-Fig. 1). ${ }^{10-14}$

\section{Description of Studies}

The 5-parallel design RCTs were published between 2014 and 2017 in Brazil $(N=4)$ and Iran $(N=1)$ and enrolled a total of 279 women with HSDD or loss of libido that caused distress. Three studies $^{11-13}$ included only postmenopausal women $(N=172$; age range $43-65$ years), and 2 studies $^{10,14}$ included only premenopausal women ( $N=107 ; 18-44$ years). Most trials excluded women with any psychiatric condition, smokers, with a history of breast or endometrial cancers, or with diabetes mellitus, cardiovascular or renal disease, and/or using any drugs that could interfere with sexual desire, including hormone therapy. All five RCTs compared T. terrestris versus placebo. One study ${ }^{13}$ had three groups: T. terrestris, tibolone, and placebo. Four trials administered the drug orally $(250 \mathrm{mg} 3$ times daily for $90-120$ days) and 1 gave the participants a syrup 


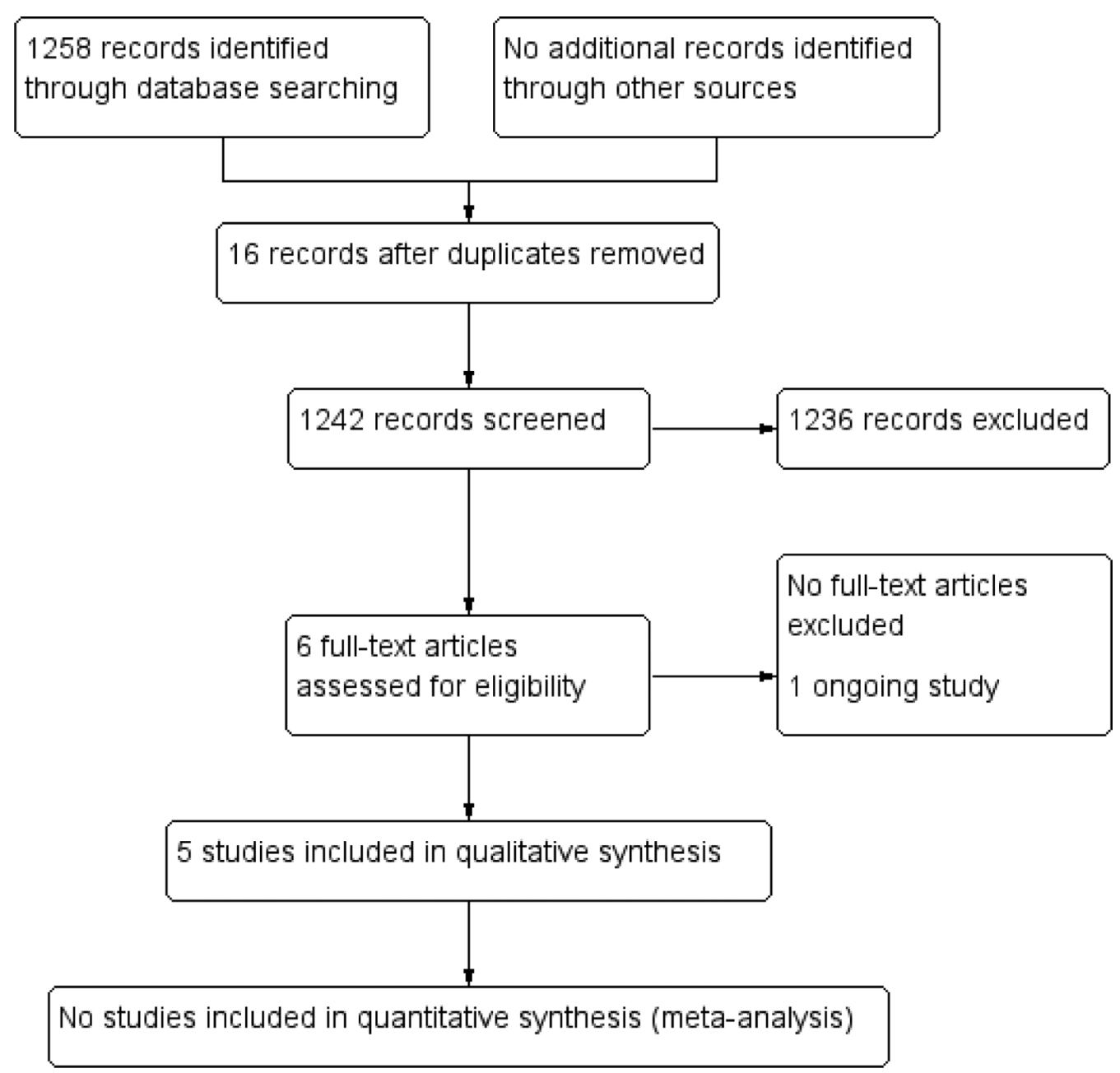

Fig. 1 Process of study selection.

containing T. terrestris extract (twice daily for 30 days). All five studies assessed sexual function as one of their outcomes; two studies also assessed testosterone levels. ${ }^{10,11}$ Only one study ${ }^{14}$ reported adverse events.

\section{Risk of Bias of Included Studies}

We classified all trials as having an unclear risk for selection bias (random sequence generation and allocation concealment) because the authors did not provide sufficient information for judgement (-Fig. 2). All studies had a low risk of bias for blinding of participants and personnel. Three studies ${ }^{10,11,14}$ had a low risk of bias for blinding of outcome assessors; the other two had an unclear risk of bias for this domain. We classified two studies ${ }^{10,11}$ as having a high risk for attrition bias because of the large number of losses (20\% and $37.5 \%$ ). The five studies reported all the outcomes planned in their registered trial protocols; we, therefore, classified them as having a low risk for reporting bias. Two studies ${ }^{11,17}$ had an unclear risk for other biases because they did not report the baseline characteristics of the study participants.

\section{Effects of Interventions}

- Table 2 presents a summary of the results of the five trials. The results of the individual studies could not be combined in metanalyses due to clinical differences in the participants (premenopausal and postmenopausal women) and lack of data (mean and/or standard deviation). We contacted the authors of the studies to obtain additional data but only one replied. $^{14}$

\section{Sexual Function Assessment}

Three studies assessed sexual function using the Female Sexual Function Index (FSFI) (scores range from 2-36, higher values indicate better function), immediately after 1 to $4^{10,11}$ months of treatment in 153 participants (46 post and 107 premenopausal women). Three studies ${ }^{15-17}$ used the Sexual Quotient Female Questionnaire (SQ-F) (scores range from $0-100$, with higher values indicating better function), to assess sexual function after 3 to 4 months of treatment in 40 premenopausal and 126 postmenopausal women.

One of the three studies that used the FSFI $^{14}$ assessed only premenopausal women and found significantly higher mean total scores in the T. terrestris group after 1 month of treatment (mean deviation [MD] 4.39; 95\% confidence interval [CI] 2.90-5.88 points; 67 participants; very low certainty evidence). The authors also reported significant increases in arousal, lubrication, orgasm, and satisfaction scores, but not in desire and pain scores (- Fig. 3 ). The other two studies ${ }^{10,11}$ (46 post 


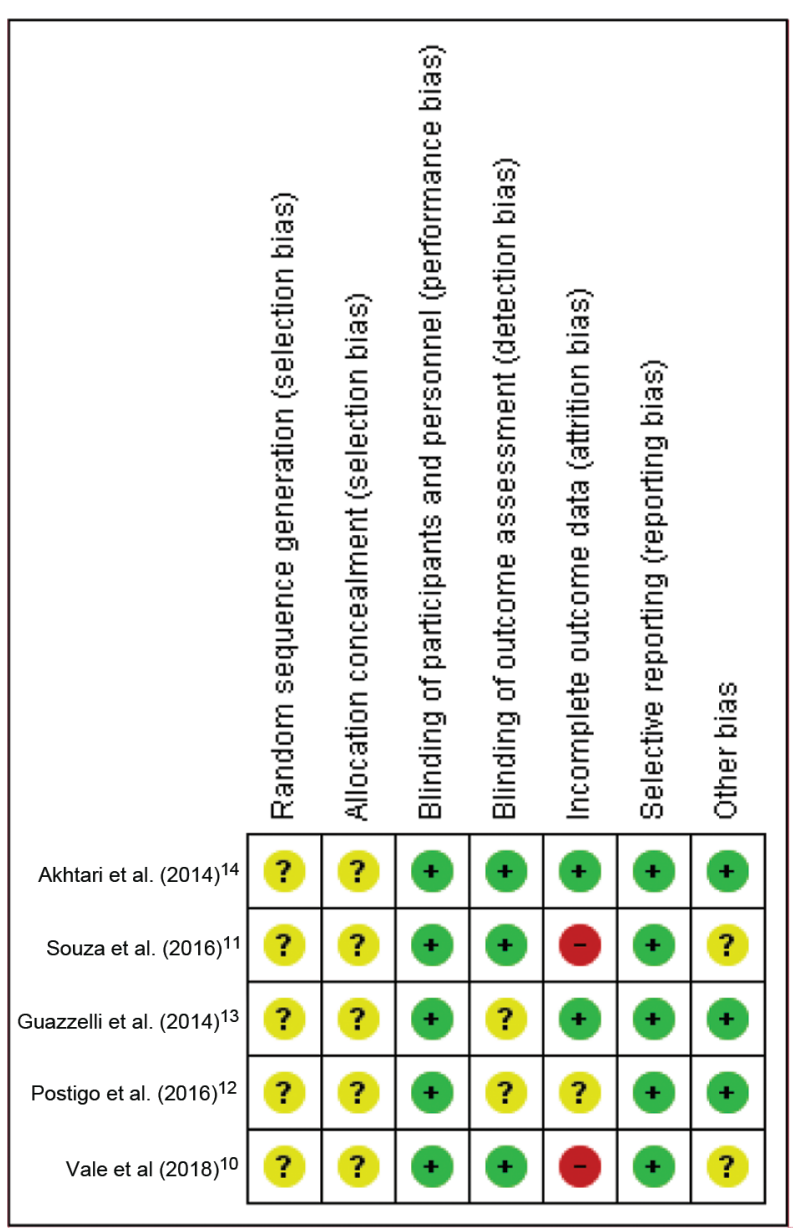

Fig. 2 Risk of bias summary.

and 40 premenopausal women) that used the FSFI found nonsignificant differences in the mean overall scores of the $T$. terrestris and placebo groups after 3 months of treatment
( $p=0.19$ and $p=0.44$, respectively). These two studies did not provide the standard deviations for these scores ( - Table 2 ).

One study ${ }^{12}$ (60 postmenopausal women) found a significant increase in SQ-F scores in the $T$. terrestris group after 3 months of treatment (MD 16.40; 95\% CI 7.67-25.13; 60 participants; very low certainty evidence). The other studies $^{10,13}$ (66 postmenopausal and 40 premenopausal women, respectively) reported only the results before and after treatment for each group and did not calculate the differences between them. One of those studies ${ }^{10}$ reported the presence of sexual dysfunction related to each domain of the SQ-F, and there was a significant improvement in all domains after treatment with $T$. terrestris $(p=0.001)$, but not after placebo $(p=0.07)$. The other study ${ }^{13}$ that assessed sexual function using the SQ-F score only reported the final mean scores in each of the three group and did not calculate the differences between them (mean final SF-Q scores: 56 points in the placebo group, 69 in the T. terrestris group and 84 in the tibolone group).

\section{Adverse Events}

Only Akhtari et al (2014) ${ }^{14}$ assessed adverse events. None of the 60 participants had serious adverse events; one participant had abdominal cramps, but the authors did not specify to which group she belonged (60 premenopausal women; very low certainty of evidence).

\section{Serum Testosterone Levels}

Two studies ${ }^{10,11}$ (96 participants) measured total serum testosterone levels after 3 months of treatment. One study ${ }^{11}$ involved only postmenopausal women and reported nonsignificant differences between the $T$. terrestris and placebo groups (MD 2.50; 95\% CI -1.79-6.79; 46 participants). The other study ${ }^{10}$ involved only premenopausal women and reported a significant increase in testosterone levels in the T. terrestris group (MD 6.60; 95\% CI 0.27-12.93; 40 participants).

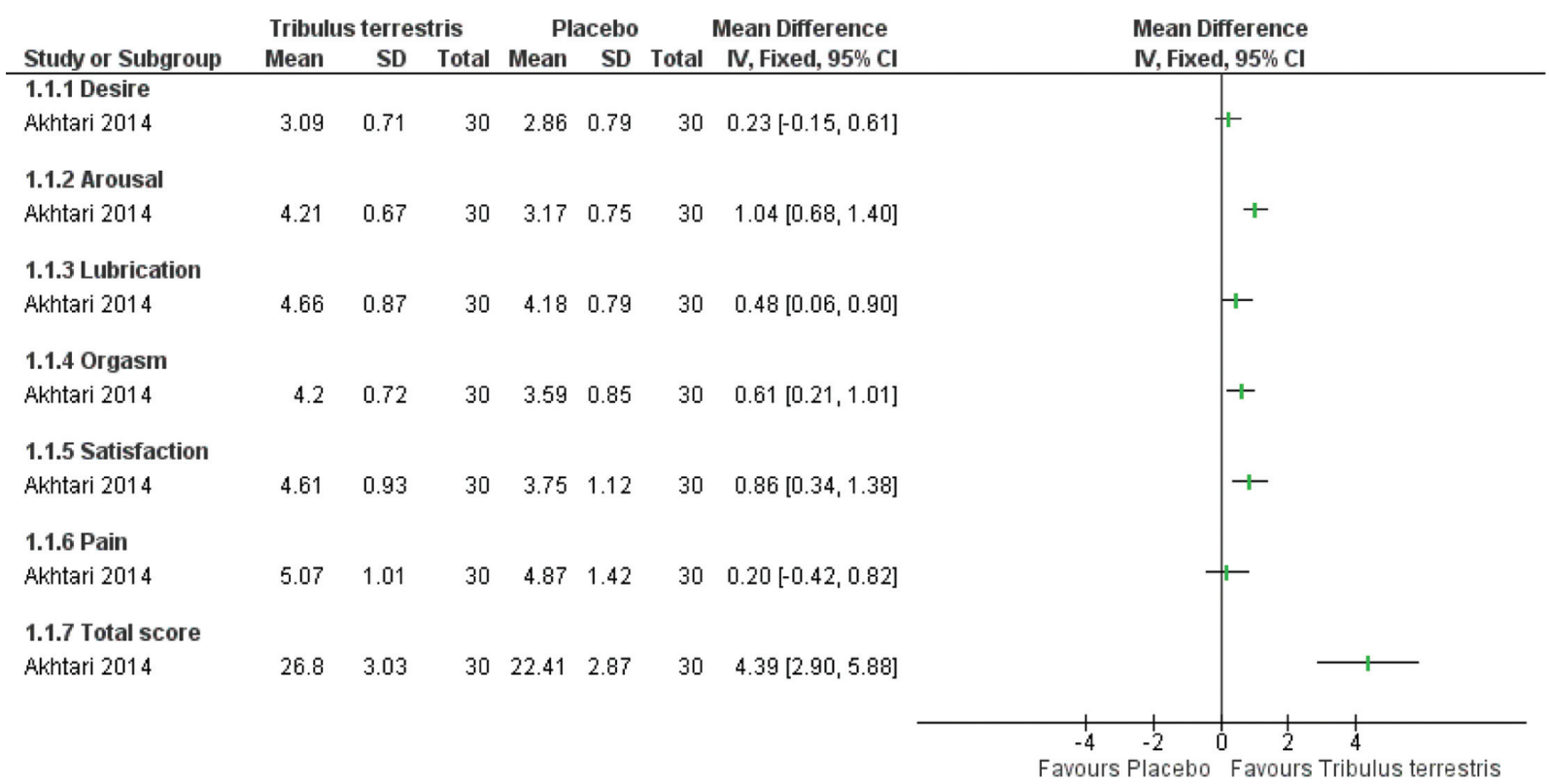

Fig. 3 Forest plot of Tribulus terrestris versus placebo (only in premenopausal women). Outcome: Sexual function measured by Female Sexual Function Index (FSFI). 
Tribulus Terrestris for Female Sexual Dysfunction Martimbianco et al. 433

Table 2 Summary of the results of the included studies

\begin{tabular}{|c|c|c|c|c|c|c|c|c|c|c|c|c|}
\hline \multicolumn{2}{|l|}{ Outcome } & \multicolumn{2}{|c|}{$\begin{array}{l}\text { Akhtari et al } \\
(2014)^{14}\end{array}$} & \multicolumn{2}{|c|}{$\begin{array}{l}\text { Souza et al } \\
(2016)^{11}\end{array}$} & \multicolumn{3}{|c|}{$\begin{array}{l}\text { Guazzelli et al } \\
(2014)^{13}\end{array}$} & \multicolumn{2}{|c|}{$\begin{array}{l}\text { Postigo et al } \\
(2016)^{12}\end{array}$} & \multicolumn{2}{|c|}{$\begin{array}{l}\text { Vale et al } \\
(2018)^{10}\end{array}$} \\
\hline & & Tribulus & Placebo & Tribulus & Placebo & Tribulus & Placebo & Tibolone & Tribulus & Placebo & Tribulus & Placebo \\
\hline $\begin{array}{l}\text { Health-related } \\
\text { quality of life }\end{array}$ & & NA & & NA & & NA & & & NA & & NA & \\
\hline $\begin{array}{l}\text { Sexual function } \\
\text { assessed by } \\
\text { FSFI (total score) }\end{array}$ & & $\begin{array}{l}26.80 \\
(3.03)^{*}\end{array}$ & $\begin{array}{l}22.41 \\
(2.87)\end{array}$ & $25.8^{\dagger}$ & $22.93^{\dagger}$ & NA & & & NA & & $25.27^{\dagger}$ & $20.29^{\dagger}$ \\
\hline \multirow{6}{*}{$\begin{array}{l}\text { Sexual function } \\
\text { assessed } \\
\text { by: FSFI } \\
\text { (sub scores) }\end{array}$} & Desire & $\begin{array}{l}3.09 \\
(0.71)\end{array}$ & $\begin{array}{l}2.86 \\
(0.79)\end{array}$ & $3.66^{\dagger}$ & $3.15^{\dagger}$ & & & & & & $3.24^{\dagger}$ & $2.88^{\dagger}$ \\
\hline & Arousal & $\begin{array}{l}4.21 \\
(0.67)^{*}\end{array}$ & $\begin{array}{l}3.17 \\
(0.75)\end{array}$ & $3.74^{\dagger}$ & $3.04^{\dagger}$ & & & & & & $3.27^{\dagger}$ & $3.08^{\dagger}$ \\
\hline & Lubrication & $\begin{array}{l}4.66 \\
(0.87)^{*}\end{array}$ & $\begin{array}{l}4.18 \\
(0.79)\end{array}$ & $4.62^{\dagger}$ & $4.39^{\dagger}$ & & & & & & $3.98^{\dagger}$ & $3.38^{\dagger}$ \\
\hline & Orgasm & $\begin{array}{l}4.20 \\
(0.72)^{*}\end{array}$ & $\begin{array}{l}3.59 \\
(0.85)\end{array}$ & $4.12^{\dagger}$ & $3.83^{\dagger}$ & & & & & & $3.84^{\dagger}$ & $3.24^{\dagger}$ \\
\hline & Satisfaction & $\begin{array}{l}4.61 \\
(0.93)^{*}\end{array}$ & $\begin{array}{l}3.75 \\
(1.12)\end{array}$ & $4.66^{\dagger}$ & $4.03^{\dagger}$ & & & & & & $4.36^{\dagger}$ & $3.34^{\dagger}$ \\
\hline & Pain & $\begin{array}{l}5.07 \\
(1.01)\end{array}$ & $\begin{array}{l}4.87 \\
(1.42)\end{array}$ & $5.0^{\dagger}$ & $4.5^{\dagger}$ & & & & & & $4.58^{\dagger}$ & $4.38^{\dagger}$ \\
\hline $\begin{array}{l}\text { Sexual function } \\
\text { assessed by SQ-F } \\
\text { (total score) }\end{array}$ & & NA & & NA & & $69 \dagger$ & $56 \dagger$ & $84 \dagger$ & $\begin{array}{l}70.9 \\
(17.6)\end{array}$ & $\begin{array}{l}56.6 \\
(17.9)\end{array}$ & $\begin{array}{l}\text { Results } \\
\text { reported } \\
\text { on the p } \\
\text { of sexua } \\
\text { function }\end{array}$ & $\begin{array}{l}\text { Nere } \\
\text { based } \\
\text { resence } \\
\text { I dys- } \\
(\%)\end{array}$ \\
\hline $\begin{array}{l}\text { Serious adverse } \\
\text { events }\end{array}$ & & No cases & & NA & & NA & & & & & NA & \\
\hline \multicolumn{13}{|l|}{$\begin{array}{l}\text { Secondary } \\
\text { outcomes } \\
\text { (Final mean (SD) }\end{array}$} \\
\hline $\begin{array}{l}\text { Serum } \\
\text { testosterone } \\
\text { levels } \\
\text { assessed by: } \\
\text { serum total } \\
\text { testosterone } \\
\text { level }\end{array}$ & & NA & & $\begin{array}{l}14.2 \\
(6.9)\end{array}$ & $\begin{array}{l}11.7 \\
(6.2)\end{array}$ & NA & & & & & $\begin{array}{l}20.5 \\
(9.7)^{*}\end{array}$ & $\begin{array}{l}13.9 \\
(10.7)\end{array}$ \\
\hline $\begin{array}{l}\text { Minor } \\
\text { adverse } \\
\text { events }\end{array}$ & & $\begin{array}{l}\text { One pati } \\
\text { reported } \\
\text { inal cram } \\
\text { (not repc } \\
\text { which gr }\end{array}$ & $\begin{array}{l}\text { ient } \\
\text { abdom- } \\
\text { nps } \\
\text { orted in } \\
\text { oup) }\end{array}$ & NA & & NA & & & & & NA & \\
\hline
\end{tabular}

Abbreviations: FSFI, Female Sexual Function Index; NA, not assessed; SD, standard deviation; SQ-F, Sexual Quotient Female Version.

*Statistically significant difference.

†Standard deviations were not reported.

None of the included studies assessed health-related quality of life.

\section{Certainty of the Evidence Assessment}

We assessed the certainty of the evidence for the primary outcomes of the main comparison (T. terrestris versus placebo). The certainty of the evidence is very low for sexual dysfunction and adverse events, after 1 and 3 months of treatment. The reasons to downgrade the evidence were the risk of bias of the trials, and imprecision due to small sample sizes. We provide explanations for each judgment in the summary of findings table (-Supplementary Table S3).

\section{Discussion}

The present systematic review evaluated the effectiveness and safety of $T$. terrestris in the treatment of women with sexual dysfunction. We identified five RCTs that could not be pooled into metanalyses due to lack of data and differences in study participants. We downgraded the certainty of the evidence to very low due to methodological limitations of the trials and imprecision attributed to small sample sizes. We had concerns about possible selection bias in all trials because the authors provided little information about the methods used for random sequence generation and allocation concealment. Based 
on the findings of single studies, $T$. terrestris, when compared with placebo, showed an improvement in sexual function scores (FSFI and SQ-F) in premenopausal and postmenopausal women, after 1 to 3 months of treatment. Regarding serum testosterone levels, 3 months of treatment with T. terrestris showed a statistically significant increase in premenopausal women, but this effect was not seen in postmenopausal women. Only one study assessed adverse events and reported that one participant had abdominal cramps but did not specify to which group she belonged. Only one study compared $T$. terrestris versus another active intervention (tibolone), but the authors did not provide quantitative data to assess differences between these interventions.

The results of the current review should be interpreted with caution because of the very low certainty of the evidence. This means that we are very unsure about the effect estimates, and future studies are likely to change the magnitude and direction of these estimates. We cannot compare our findings to those of other reviews because, to the best of our knowledge, this is the first systematic review about this intervention.

Our study had several strengths starting with its strict adherence to the methodological recommendations of the Cochrane Handbook and the PRISMA reporting guidelines. We also conducted a broad and sensitive literature search, including gray literature and hand search, to try to identify all potentially relevant studies. The main limitation of the review was the lack of success in obtaining additional information from trial authors. These details would have been important to assess the risk of selection bias of all trials, and additional quantitative data could have allowed us to perform meta-analyses.

The findings of our review should alert clinicians and patients that there is very low certainty evidence regarding the effects (benefits and harms) of T. terrestris for the treatment of women with sexual disorders. Current evidence does not support the routine use of $T$. terrestris in clinical practice.

There is a need for additional, well designed, and well conducted RCTs to assess the effects of this intervention for FSD in pre and postmenopausal women. The authors of these trials should adhere to the Consolidated Standards of Reporting Trials (CONSORT) reporting guidelines. This will help to reduce the uncertainty of effect estimates and allow more robust conclusions.

\section{Conclusion}

The present systematic review found very low-certainty evidence, from small single studies, that $T$. terrestris increases sexual function scores (FSFI and SQ-F) in premenopausal and postmenopausal women. However, these results should be interpreted with caution since future studies are likely to change the magnitude and direction of our estimates. More trials are needed to support or refute the use of T. terrestris in clinical practice.

\footnotetext{
Contributions

Drafting the study protocol (all authors); development of the search strategy (COCL and RR); selection of studies and data extraction (RLP, ALCM and RR); assessment of
}

risk of bias of the included studies (RLP and ALCM); statistical analyses (all authors); interpretation of the results (all authors); drafting the review manuscript (all authors). Revision of the content (RR). All authors read and approved the final manuscript.

\section{Conflict of Interests}

The authors have no conflict of interests to declare.

\section{References}

1 Faubion SS, Rullo JE. Sexual dysfunction in women: a practical approach. Am Fam Physician. 2015;92(04):281-288

2 Mazaro-Costa R, Andersen ML, Hachul H, Tufik S. Medicinal plants as alternative treatments for female sexual dysfunction: utopian vision or possible treatment in climacteric women? J Sex Med. 2010;7(11):3695-3714. Doi: 10.1111/j.1743-6109.2010.01987.x

3 Weinberger JM, Houman J, Caron AT, Anger J. Female sexual dysfunction: a systematic review of outcomes across various treatment modalities. Sex Med Rev. 2019;7(02):223-250. Doi: 10.1016/j.sxmr.2017.12.004

4 Parish SJ, Meston CM, Althof SE, Clayton AH, Goldstein I, Goldstein SW, et al. Toward a more evidence-based nosology and nomenclature for female sexual dysfunctions-part III. J Sex Med. 2019;16 (03):452-462. Doi: 10.1016/j.jsxm.2019.01.010

5 Shifren JL, Monz BU, Russo PA, Segreti A, Johannes CB. Sexual problems and distress in United States women: prevalence and correlates. Obstet Gynecol. 2008;112(05):970-978. Doi: 10.1097/ AOG.0b013e3181898cdb

6 Aslan E, Fynes M. Female sexual dysfunction. Int Urogynecol J Pelvic Floor Dysfunct. 2008;19(02):293-305. Doi: 10.1007/ s00192-007-0436-3

7 Frühauf S, Gerger H, Schmidt HM, Munder T, Barth J. Efficacy of psychological interventions for sexual dysfunction: a systematic review and meta-analysis. Arch Sex Behav. 2013;42(06):915-933. Doi: 10.1007/s10508-012-0062-0

8 Su L, Chen G, Feng SG, Wang W, Li ZF, Chen H, et al. Steroidal saponins from Tribulus terrestris. Steroids. 2009;74(4-5):399-403. Doi: $10.1016 /$ j.steroids.2008.12.008

9 Basson R, Leiblum S, Brotto L, Derogatis L, Fourcroy J, Fugl-Meyer $\mathrm{K}$, et al. Definitions of women's sexual dysfunction reconsidered: advocating expansion and revision. J Psychosom Obstet Gynaecol. 2003;24(04):221-229. Doi: 10.3109/01674820309074686

10 Vale FBC, Zanolla Dias de Souza K, Rezende CR, Geber S. Efficacy of Tribulus Terrestris for the treatment of premenopausal women with hypoactive sexual desire disorder: a randomized doubleblinded, placebo-controlled trial. Gynecol Endocrinol. 2018;34 (05):442-445. Doi: 10.1080/09513590.2017.1409711

11 de Souza KZ, Vale FBC, Geber S. Efficacy of Tribulus terrestris for the treatment of hypoactive sexual desire disorder in postmenopausal women: a randomized, double-blinded, placebo-controlled trial. Menopause. 2016;23(11):1252-1256. Doi: 10.1097 /GME.0000000000000766

12 Postigo S, Lima SMRR, Yamada SS, dos Reis BF, da Silva GM, Aoki T. Assessment of the effects of tribulus terrestris on sexual function of menopausal women. Rev Bras Ginecol Obstet. 2016;38(03): 140-146. Doi: 10.1055/s-0036-1571472

13 Guazzelli RM, Lima SMRR, Postigo S, Martins CPB, Yamada SS. Estudo dos efeitos do Tribulus terrestris e da tibolona em mulheres com disfunção do desejo sexual após a menopausa. Arq Med Hosp Fac Cienc Med Santa Casa São Paulo.. 2014;59 (01):20-26

14 Akhtari E, Raisi F, Keshavarz M, Hosseini H, Sohrabvand F, Bioos S, et al. Tribulus terrestris for treatment of sexual dysfunction in women: randomized double-blind placebo - controlled study. Daru. 2014;22(01):40. Doi: 10.1186/2008-2231-22-40 
15 Higgins J, Green S, Eds. Cochrane handbook for systematic reviews of interventions [Internet]. Version 5.1.0. London: The Cochrane Collaboration; 2011 [cited 2019 Aug 10]. Available from: https:// handbook-5-1.cochrane.org/

16 Moher D, Liberati A, Tetzlaff J, Altman DG; PRISMA Group. Preferred reporting items for systematic reviews and meta-analyses: the PRISMA statement. BMJ. 2009;339:b2535. Doi: 10.1136/bmj.b2535

17 Rosen R, Brown C, Heiman J, Leiblum S, Meston C, Shabsigh R, et al. The Female Sexual Function Index (FSFI): a multidimensional self-report instrument for the assessment of female sexual function. J Sex Marital Ther. 2000;26(02):191-208. Doi: 10.1080/009 262300278597

18 Abdo CHN. Development and validation of female sexual quotient: a questionnaire to assess female sexual function. RBM Rev Bras Med.. 2006;63(09):477-482
19 Ouzzani M, Hammady H, Fedorowicz Z, Elmagarmid A. Rayyan-a web and mobile app for systematic reviews. Syst Rev. 2016;5(01): 210. Doi: 10.1186/s13643-016-0384-4

20 Review Manager (RevMan). Version 5.3 [Computer program]. Copenhagen: The Nordic Cochrane Centre/The Cochrane Collaboration; 2014

21 Guyatt GH, Oxman AD, Schünemann HJ, Tugwell P, Knottnerus A. GRADE guidelines: a new series of articles in the Journal of Clinical Epidemiology. J Clin Epidemiol. 2011;64(04):380-382. Doi: 10.1016/j.jclinepi.2010.09.011t

22 McMaster University. GRADEpro GDT: GRADEpro Guideline Development Tool [Computer program]. Hamilton: Evidence Prime; 2015 